\title{
TITIK NOL KILOMETER KOTA YOGYAKARTA SEBAGAI RUANG TERBUKA PUBLIK DITINJAU DARI DIMENSI FUNGSIONAL, SOSIAL, DAN VISUAL
}

\author{
Mustika Kusumaning Wardhani \\ Megister Teknik Arsitektur Universitas Diponegoro \\ Penulis Korespondensi e-mail : Kweemustika@gmail.com
}

\begin{abstract}
Yogyakarta is known as the city with a rich cultural heritage philosophical meaning of life for their peoples. One part of the Javanese culture is the social activity of the community which is contained in the public space. Public space is one of the elements that make up the urban face as a space of social interaction and become a city icon. The purpose of this research is to know the role of Titik nol kilometer Yogyakarta area in terms of function dimensions, social dimensions, and visual dimensions. The research method used is descriptive qualitative by explaining the role of public open space by using graphical analysis. The results of the analysis show that the zero point zones are public open spaces that contain a variety of activities that shape the social interaction of its users from various societies. While the aspects of the dimensions of function, social, and visual form a sense of place with a strong character, unique, and distinctive.
\end{abstract}

Keywords: Public space, Titik nol Kilometer Yogyakarta, Urban dimension

\begin{abstract}
ABSTRAK
Kota Yogyakarta dikenal sebagai kota dengan warisan kebudayaan yang kaya akan makna filosofi hidup bagi warga masyarakatnya. Salah satu bagian dari kebudayaan Jawa adalah kegiatan sosial masyarakatnya yang diwadahi pada ruang terbuka publik. Ruang publik adalah bagian dari unsur elemen yang menggambarkan citra perkotaan sebagai ruang interaksi sosial dan menjadi ikon sebuah kota. Tujuan dari penelitian ini adalah untuk mengetahui peran kawasan titik nol kilometer Kota Yogyakarta sebagai ruang terbuka publik ditinjau dari dimensi fungsi, dimensi sosial, dan dimensi visual. Metode penelitian yang digunakan yaitu berupa deskriptif kualitatif dengan menjelaskan peran ruang terbuka publik dengan menggunakan analisa grafis. Hasil dari analisi menunjukkan bahwa kawasan titik nol kilometer merupakan ruang terbuka publik yang memuat berbagai macam kegiatan yang membentuk interaksi sosial penggunanya dari berbagai kalangan masyarakat. Sedangkan dari aspek dimensi fungsi, sosial, dan visual membentuk sense of place dengan karakter yang kuat, unik, dan khas.
\end{abstract}

Kata Kunci: Ruang publik, Titik nol Kilometer Yogyakarta, Dimensi Perkotaan 


\section{PENDAHULUAN}

Kota Yogyakarta dikenal sebagai kota dengan warisan kebudayaan yang kaya akan makna filosofi hidup bagi warga masyarakatnya. Salah satunya tentang keberadaan sumbu imajiner yang menghu- bungkan antara gunung Merapi, Tugu pu- tih, Keraton, Panggung Krapyak, dan laut selatan (Parangtritis). Secara kosmik, sumbu imajiner menyampaikan makna akan kesatuan antara Tuhan, manusia, dan dosa. Kawasan titik nol kilometer Kota Yogyakarta merupakan salah satu kawa- san yang membentuk citra Kota yang diperkuat dengan keberadaan path, district, edge, nodes, and landmark dan bagian dari sumbu imajiner Kota Yogya- karta itu sendiri. Selain daripada berperan sebagai citra Kota Yogyakarta, kawasan ini dikelilingi oleh bangunan-bangunan peninggalan masa kolonialisme berlang- gam indis. Terdapat area hijau dengan pepohonan yang rindang sebagai peneduh serta bangku taman yang khas yang dipergunakan bersama.

Ruang-ruang yang berada di antara bangunan disebut ruang publik dalam urban design dan berfungsi sebagai salah satu elemen Perancangan Kota. Ruang publik memiliki fungsi elemen kota yang mempunyai karakternya masing-masing, sehingga mempunyai peran dalam interaksi sosial untuk warga, maupun aktivitas ekonomi rakyat serta dapat menjadi lokasi aktualisasi dari suatu budaya. Seiring perkembangan jaman, teknologi memberikan pengaruhnya terhadap pembentukan sikap dan perilaku manusia pada bentuk-bentuk ruang perkotaan yang direncanakan. Kebutuhan akan fasilitas ruang publik terus bertambah seiring dengan meningkatnya manusia dan teknologi, sehingga memberikan dampak dari aspek segi kualitas desain sampai pada material dan perawatannya.

Menurut Budihardjo dan Sujarto (2005) ruang terbuka publik adalah ruang yang diperuntukan sebagai kebutuhan untuk lokasi perjumpaan dan kegiatan aktivitas bersama. Aktivitas yang mempunyai spirit of place sebagai potensi keunikan yang dapat menarik bagi pengunjung sehingga dapat terjadi pencampuran antara fungsi, seni, arsitektur, dan kegiatan di ruang publik (Garnham:1985).

Ruang menjadi elemen utama yang penting pada bidang keilmuan arsitektur. Ruang mempunyai hubungan yang sangat dekat aspek psikologi emosional dan dimensional. Ruang sebagai suatu wadah aktivitas manusia berfungsi sebagai wadah bergerak dan beraktivitas atau kegiatan yang direncanakan. Arsitektur memberi pandangan terhadap ruang yang memiliki keterkaitan erat dengan aktivitas manusia, dimana ruang dapat tercipta melalui aktivitas manusia 
yang berada di dalamnya. Ruang akan tidak mempunyai makna bila terjadi kekosongan aktivitas didalamnya. Disatu sisi kekosongan tersebut menjadi suatu hal yang biasa terjadi dan diabaikan. Sehingga perlu peran dari arsitektur yang hakekatnya mampu menjawab tantangan permasalahan kekosongan ini. Sehingga efisiensi ruang menjadi suatu hal yang penting (Firdausi, Fairuuz Syafiqoh; Prsetyo, 2017). Ruang publik yang memiliki fungsi elemen kota berkontribusi dalam pembentukan karakter visual dan mempunyai fungsi interaksi sosial didalamnya. Hal inilah yang mendasari penulis untuk membahas ruang terbuka publikdi kawasan titik nol kilometer Kota Yogyakarta melalui dimensi fungsional, dimensi sosial, dan dimensi visual.

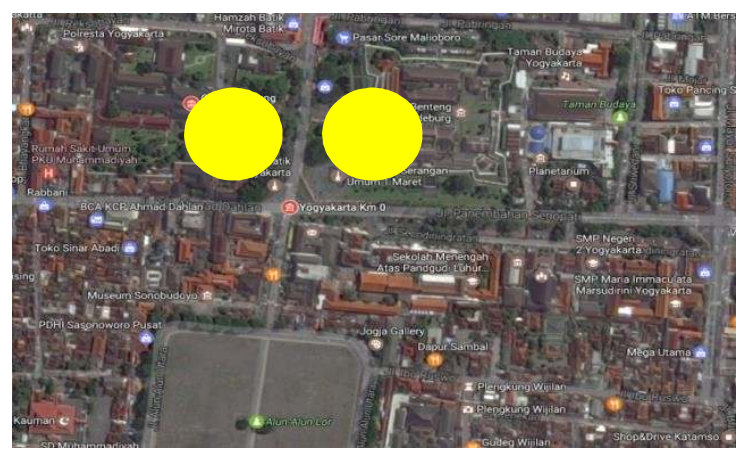

Gambar 1. Posisi keberadaan ruang terbuka publik di Kawasan Titik nol Kilometer Kota Yogyakarta Sumber: www.googlemaps.com, 2017

\section{METODOLOGI}

Ruang lingkup dalam penelitian mencakup pada lingkup substansial dan lingkup spasial yaitu:

1. Ruang lingkup secara substansial membahas tiga variabel dimensi ruang terbuka publik yaitu dimensi fungsional, dimensi Sosial, and dimensi visual.

2. Secara Spasial membahas kawasan titik nol kilometer Kota Yogyakarta dengan batasan wilayah sebagai berikut:

Metode Penelitian menggunakan metodologi penelitian kualitatif Menurut Bodgan dan Taylor (sebagaimana yang dikutip oleh Lexy J. Moleong), metodologi kualitatif adalah prosedur penelitian yang menghasilkan data deskriptif berupa kata- kata tertulis atau lisan dari orang dan perilaku yang dapat diminati. Penelitian ini langsung dilakukan di lapangan dan dilengkapi dengan sejumlah responden sebagai narasumber untuk kelengkapan data. Metode pengamatan dan pengum- pulan data yang digunakan penulis adalah: 
- Metode Primer

Metode Primer diterapkan untuk memperoleh data secara langsung sesuai dengan kondisi sebenarnya. Pengumpulan data dengan metode primer dilakukan dengan cara:

a) Observasi, yaitu dengan melakukan pengamatan langsung serta mencatat dan mendokumentasikan apa yang dilihat dan didapat sesuai dengan data yang dibutuhkan sehingga dapat mengetahui proses penelitian secara langsung

b) Wawancara, yaitu dengan mengadakan tanya jawab secara langsung dengan pihak yang terkait untuk memperoleh data yang dibutuhkan

- Metode Sekunder

Metode sekunder diterapkan untuk memperoleh teori dan informasi pendukung yan diperlukan dalam penyusunan karya ilmiah dengan cara studi pustaka, yaitu dengan mempelajari literatur terkait dengan masalah dan obyek yang akan dibahas. Literatur bisa diperoleh melalui berbagai media, baik media konvensional (cetak) ataupun media non cetak (elektronik).

\section{Tinjauan Teori}

Ruang adalah wadah yang meliputi ruang darat, ruang laut, dan ruang udara, termasuk ruang di dalam bumi sebagai satu kesatuan wilayah, tempat manusia dan makhluk lain hidup, melakukan kegiatan, dan memelihara kelangsungan hidupnya. Pola ruang adalah pembagian peruntukan penggunaan ruang dalam suatu wilayah yang dibagi menjadi dua fungsi ruang yaitu fungsi kawasan lindung sebagai keseimbangan lingkungan hidup serta sosial dan fungsi pengembangan kawasan budidaya untuk pengembangan perkotaan kedepannya (Rahman, 2017). Ruang publik dapat masuk dalam kategori kawasan lindung bila dilihat sebagai ruang terbuka hijau, menurut pengertian umum, ruang publik yaitu ruang-ruang yang berorientasi manusia (people oriented spaces). Stephen Carr (1992) meng-identifikasikan lima kebutuhan dasar kepuasan pengguna ruang publik: Kenyamanan, relaksasi, keterikatan pasif \& aktif, dan penemuan. Ruang terbuka publik merupakan ruang terbuka hijau yang dimiliki dan dikelola oleh pemerintah daerah kota dan digunakan untuk kepentingan masya-rakat secara umum. Pengertian ruang publik secara singkat merupakan suatu ruang yang berfungsi untuk kegiatan-kegiatan masyarakat yang berkaitan dengan aspek sosial, ekonomi, dan budaya. Darmawan (2003) menyatakan bahwa dalam perencanaan kota perlu diuraikan fungsi daripada ruang publik yang meiputi:

1) Sebagai wadah interaksi, komunikasi warga, baik interaksi formal hingga non formal 
2) Membentuk koridor-koridor yang dapat menjadi wadah dan pembentuk batasan ruang sesuai penggunaan bangunan pada kawasan sekitar dan sebagai ruang transit.

3) Sebagai tempat pedagang kaki lima yang menjajakan makanan dan minuman, souvenir, dan jasa entertainment

4) Sebagai paru-paru kota yang menyegarkan kawasan sekaligus sebagai ruang evakuasi untuk menyelamatkan masyarakat apabila terjadi bencana alam.

Ruang terbuka dimanfaatkan oleh masyarakat sebagai wahana atau ruang untuk berkomunikasi dengan anggota masyarakat yang lainnya. Kegiatan-kegiatan yang terjadi di ruang terbuka tidak hanya dilakukan oleh satu anggota masyarakat saja melainkan lebih dari satu anggota masyarakat yang kemudian membahas topik-topik atau bahasan yang sama diantara mereka dan menimbulkan komunikasi diantara anggota masyarakat itu sendiri (Ardani, Krisna Sandy; Rini, Hartati Sulistyo; Iswati, 2016). Ruang terbuka yang menjadi ruang public, Secara konseptual, ruang publik semacam ini memiliki fungsi sebagai ranah yang "memanusiakan" masyarakat, karena banyak kegiatan dan interaksi sosial yang bisa dilakukan di ruang public. Sedangkan dalam studi komunikasi, khususnya komunikasi publik dalam konteks pembangunan perkotaan, fungsi ruang publik sangatlah penting. Berada dalam tengah tekanan hidup di perkotaan, masyarakat membutuhkan ruang untuk bernapas, bergerak, dan berinteraksi dengan warga lain dengan penuh sentuhan manusiawi. Itulah wujud ruang publik sebagai ruang yang aksesibel bagi warga baik secara individu maupun kelompok (Gani, 2017).

Ruang public memiliki beberapa fungsi Carmona, et al : 2008), yaitu :

1. Positive space. Seperti namanya, ruang ini digunakan bagi aktivitas-aktivitas yang bermuara pada arah positif. Ruang ini biasanya dikelola oleh pemerintah. Mempunyai bentuk alami, semi alami dari suatu ruang public maupun pada ruang terbuka public.

2. Negative space. Kebalikan dari ruang positive, ruang ini mengarah pada kegiatan yang terbentuk kurang baik maupun kurang terkelola. Sehingga mengakibatkan penurunan fungsi ruang terbuka public dari aspek kenyamanan dan keamanan.

3. Ambiguous space. Merupakan ruang pendukung yang menjadi kegiatan peralihan masyarakat dari aktivitas utama contohnya adalah ruang bersantai di pertokoan, café, rumah peribadatan, ruang rekreasi, dan lain sebagainya.

4. Private space. Adalah ruang punyai dengan privat oleh masyarakat, pada umumnya seperti ruang terbuka privat, halaman rumah dan ruang di dalam bangunan. 
Terus berkembangnya perkotaan membuat ketersediaan ruang publik sebagai wadah untuk beraktivitas akan semakin sedikit, hal dikarenakan pertumbuhan penduduk yang terus meningkat namun ketersedian ruang publik yang berfungsi sebagai wadah aktivitas tidak kunjung bertambah. Akhirnya, ruang publik yang sudah ada dituntut lebih oleh masyarakat dalam mengakomodasi segala kebutuhannya yang mana tuntutan akan pemenuhan kebutuhan tersebut berdampak pada pola aktivitas dan pemanfaatan terhadap ruang di dalamnya. Pemanfaatan ruang publik yang ada bisa saja menjadi kurang teratur atau tidak sesuai dengan fungsi yang seharusnya (Puspasari, Ernawati, \& Suryasari, 2015).

Penggunaan taman kota di negara maju saat ini telah berubah, taman kota saat ini beralih dari ruang terbuka pasif untuk sekedar "melihat", menjadi ruang ataktrif yang lebih dinamis (Setiawan, 2017). Warga dari berbagai tingkatan kehidupan sosial-ekonomi-budaya, semua tingkat warga dari tingkat pendidikan, segala golongan umur dan tingkat kepenting heterogen akan selalu tertarik untuk mengunjungi ruang publik. Dari aspek esesnsial maka ruang public mempunyai beberapa kriteri yaitu:

1. Maeningful, menciptakan pemaknaan ruang individu dan kelompok bagi masyarakat.

2. Responsive, mencakup berbagai kegiatan yang diingikan oleh pengguna sehingga dapat tercipta aktivitas kegiatan yang diinginkan pada ruang tersebut.

3. Democratic, menciptaka rasa keterbukaan, kebebasan dan tidak ada diskriminasi bagi semua lapisan warga.

Tatanan ruang kota selalu dihubungkan dengan jaringan jalan dan lingkungan sebagai tempat kegiatan masyarakat. Hal Yang berubah mengikuti perkembangan perkotaan adalah jalan disekitar bangunan dan lapangan atau alun-alun (ruang publik), sedangkan bangunan dan monumen (privat) cenderung lebih stabil dan akan memberikan karakter tersendiri bagi suatu kota (boyer, 1994). Suatu lingkungan dianggap baik apabila mampu menerima perubahan dimasa depan, mengakomodasikan keadaan saat ini tanpa mengancam keber langsungan masa lalu sustainable (Burtenshaw, 1991).

Carmona dalam bukunya "Public Places Urban Space” (2003), menyebutkan ruang terbuka public memiliki beberapa fungsi, yaitu peran ekonomi, kesehatan, sosial dan lingkungan. Keberhasilan ketepatan fungsi public space adalah pada movement khususnya pedestrian yang dapat dengan mudah dipahami secara visual pemisahan antara pedestrian dengan pergerakan mobil, dan sebagai jeda sebuah perjalanan (transit). 


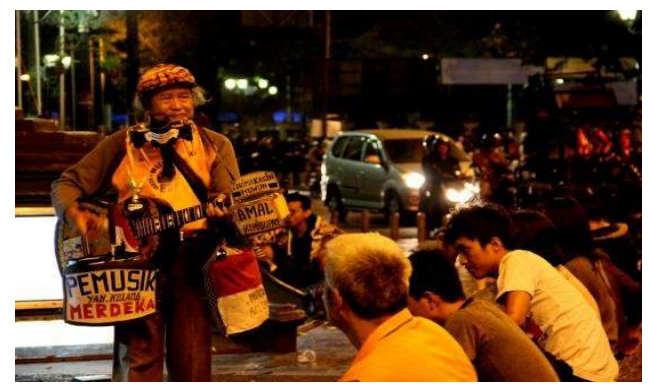

Gambar 2. Seorang pemusik yang sedang menghibur pengguna ruang publik (Sumber: Dokumentasi Pribadi, 2017)

Carr dalam Carmona, et al (2003) menyebutkan bahwa ada peran dari mengemukakan adanya peran dari aktivitas pasif maupun aktif pada penggunaan ruang publik. Pembentukan nilai pengalaman terbentuk dari terjadinya proses interaksi pasif dan aktif, hal menunjukkan bahwa pemanfaatan dari ruang publik terjadi oleh interaksi dengan proses yang berbeda. Interkasi sosial merupakan hasil dari suatu ruang dengan kondisi lingkungan nyaman sebagai wadah interaksi. Dari hanya aktivitas pasif seperti hanya duduk menikmati ruang disekitar saja dapat menjadi aktif saat muncul obrolan antar pengunjung ruang untuk saling berinteraksi membahas suatu hal baik secara berdua maupun secara komunitas, hal ini menunjukkan bahwa interaksi sosial telah terjadi melalui aktivitas pasif-aktif.

Menilik pada kondisi, bahwa ruang adalah arena di mana pertarungan antara berbagai pihak. Dalam masyarakat kapitalistik modern, semua pihak yang memiliki kepentingan akan mencoba untuk saling mendominasi pemakaian atau pemanfaatan atas ruang yang ada, dengan berbagai instrumen otoritatif, dan berupaya mereproduksi pengetahuan untuk mempertahankan hegemoni atas pemanfaatan ruang (Adiprasetio \& Jaya, 2017).

Kualitas visual meliputi seberapa kuat struktur ruang terhadap kawasan yang dipengaruhi oleh pembagian hirarki ruang dan memiliki hubungan yang saling (Trancik, 1986). Aspek estetika menjadi cara pandang pada deimensi visual perancaan kota. Persepsi yang dikemas dalam desain juga menjadi pembentukan dimensi visual. Ruang aktivitas publik yang baik harus nyaman karena nyamannya suatu RTH akan meningkatkan produktifitas orang didalamnya. Aspek kenyamanan pada taman kota adalah suhu udara, kelembaban udara dan kebisingan (Prasetya \& Hidayati, 2016). Melihat hal tersebut maka selera publik terhadap kemampuannya menilai dan merasakan ligkungan menjadi pertimbangan dalam dimensi 
visual. Estetika menjadi dasar perancangan maupun peniliaan dari elemen pembentukan struktru dan ruang kota. (Carmona 2003).

\section{PEMBAHASAN DAN HASIL}

Provinsi Daerah Istimewa Yogyakarta dikenal sebagai salah satu pusat kebudayaan khususnya budaya jawa. Hal ini didukung oleh keberadaan dua buah Kraton yaitu Kraton Kasultanan Nga- yogyakarta Hadiningrat dan Kadipaten Pura Pakualaman. Kebudayaan yang tumbuh dan berkembang di masyarakat cukup beragam khususnya peninggalan bangunan bersejarah dan petilasan yang turut melengkapi predikat kota budaya. Keragaman potensi budaya yang terdapat di Kota Yogyakarta terdiri dari budaya tangible (fisik) dan intangible (non fisik). Potensi budaya fisik antara lain kawasan dan benda cagar budaya sedangkan potensi non fisik seperti gagasan, sistem nilai atau norma, sistem sosial yang ada pada masyarakat menyumbang kontribusi besar pada perancangan kota.

Model yang digunakan dalam tata ruang wilayah Kota Yogyakarta adalah corridor development atau pemusatan intensitas kegiatan manusia pada suatu koridor tertentu yang berfokus pada pusat kota dan jalan koridor sekitarnya. Aspek pengendalian dan pengarahan pembangunan dilakukan lebih menonjol dalam koridor skala prioritas.

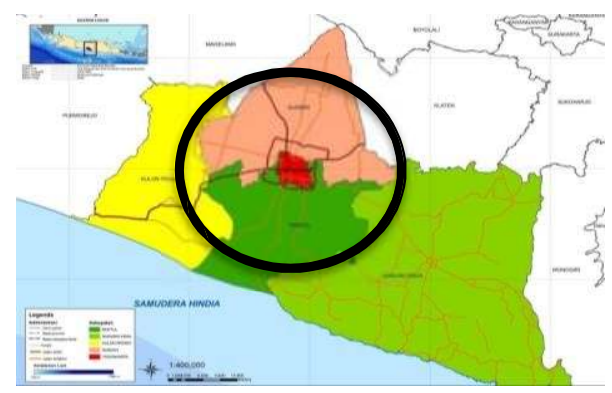

Gambar 3. Bentuk Radial Konsentris Kota Yogyakarta Sumber: www.googlemaps.com

\section{Tinjauan Kawasan Titik Nol Kilometer Kota Yogyakarta}

Lynch menguraikan tiga model bentuk kota berdasarkan pada faktor budaya yang secara dominan mempengaruhi kota, yaitu: the city of faith, the city as a machine and the city as organism. Dalam teori the city of faith, aturan magis merupakan faktor yang mengatur hubungan antara elemen kawasan sebagai sebuah model kota yang berkaitan dengan Tuhan dan 
dunia makrokosmos. Pola kota yang ditemui cenderung berbentuk geometris bermakna kosmologis dan berorientasi pada satu garis lurus (aksis) yang menghubungkan antara dunia makrokosmos dengan dunia mikrokosmos.
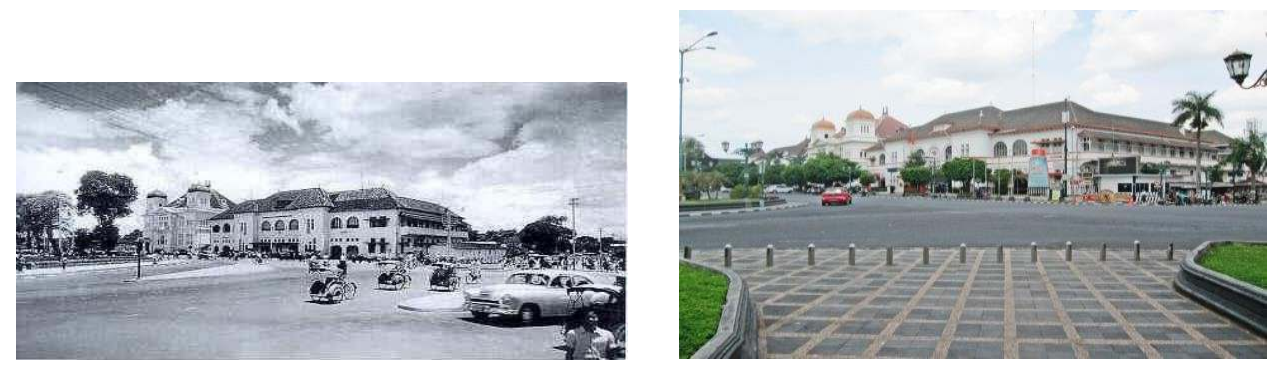

Gambar 4. Kawasan titik nol kilometer masa lalu yang masih berfungsi sebagai pusat kegiatan pemerintahan dan kawasan titik nol kilometer sekarang sebagai ruang terbuka publik Sumber: www.google.com dan Dokumentasi Pribadi, 2017

Kawasan titik nol Kilometer merupakan salah satu bagian dari sumbu imajiner yang menghubungkan Tugu Pal Putih dengan Alun-alun adalah kawasan titik nol kilometer. Di sekitar kawasan titik nol kilometer terdapat pusat pemerintahan, perdagangan, dan pariwisata. Kawasan titik nol sangat strategis untuk dikembangkan sebagai pusat aktivitas masyarakat dan wisatawan, khususnya aktivitas budaya dan pariwisata. Adapun potensi yang terdapat disekitar kawasan titik nol kilometer Kota Yogyakarta yang membentuk Citra Kota adalah sebagai berikut:

Tabel 1. Potensi Wisata kawasan titik nol kilometer Kota Yogyakarta

\begin{tabular}{|l|l|}
\hline Museum Benteng Vredeburg & Pasar Beringharjo \\
\hline Taman Budaya Yogyakarta & Pecinan Ketandan \\
\hline Taman Pintar & Kawasan Malioboro \\
\hline Gedung Agung & $\begin{array}{l}\text { Alun-Alun Utara dan Keraton } \\
\text { Yogyakarta }\end{array}$ \\
\hline Gebung BNI & Monumen Serangan Umum 1 Maret \\
\hline Gedung Bank Indonesia (BI) & $\begin{array}{l}\text { Jam kota/stadtklok dan Gaug (sirine } \\
\text { kuno) }\end{array}$ \\
\hline Kantor Pos Besar (pusat) & Museum Sonobudoyo \\
\hline
\end{tabular}

Sumber: Pengamatan Pribadi, 2017 


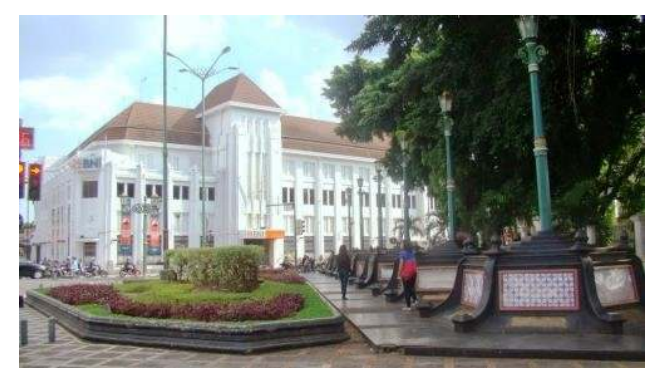

Gambar 5. View bangunan Indis yang ditawarkan ruang publik kawasan titik nol Kilometer bagian barat

Sumber: Dokumentasi Pribadi, 2017

Pandangan yang lebih luas terhadap variasi dan karakter ruang publik dapat terbentuk dan muncul secara khas seiring dengan sejarah yang dimiliki oleh kota. Sejarah perkembangan perkotaan berhubungan dengan ruang dan waktu sebagai bagian dari konsep atau makna setiap periode berlangsungnya suatu peristiwa masa lampau, sekarang, dan yang akan datang

\section{Pembahasan Dimensi Fungsional}

Fungsi dalam rancang kota menekankan manusia sebagai subyek dan juga pengguna dari lingkungan. Sebuah kota yang fungsional memiliki jiwa yang menimbulkan keterikatan hubungan emosional antar manusia dan lingkungan serta manusia lainnya. Sehingga muncul dorongan interaksi di dalamnya. Jiwa pada suatu tempat ini sering kita kenal dengan istilah genius loci yang meyakini bahwa sebuah lingkungan fisik memiliki sifat atau karakter bawaan yang unik. Hal ini kerap kali kita jumpai pada ruang publik yang memberi makna pada interaksi sosial yang terjadi disana. Fungsi ruang terbuka publik dapat diamati melalui dua aspek yaitu secara sosial dan ekologi.
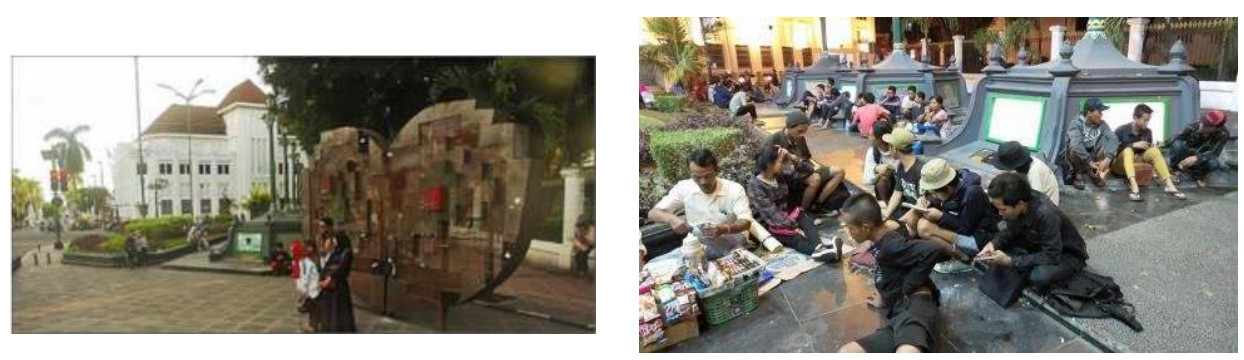

Gambar 6. Intensitas kegiatan yang dilakukan pada siang hari dan intensitas pengguna ruang terbuka publik pada malam hari Sumber: Dokumentasi Pribadi, 2017 
Fungsi secara sosial mencakup komunikasi dan sosialisasi, tempat bermain dan berolah raga, mendapatkan udara segar, menunggu kegiatan lain, pembatas antar massa bangunan, penghubung satu tempat dengan yang lain, sarana pendidikan, dan sarana penyuluhan atau orasi. Sedangkan dipandang secara ekologis, fungsi ruang terbuka publik memperlunak arsitektur bangunan, penyerap air hujan, pencegah banjir, menyegarkan udara perkotaan, mereduksi panas, menjaga keseimbangan ekosistem. Menurut (Darmawan,2003) secara umum fungsi public space adalah sebagai berikut:

- Sebagai wadah interaksi, komunikasi warga, baik interaksi formal hingga non formal

- Membentuk koridor-koridor yang dapat menjadi wadah dan pembentuk batasan ruang sesuai penggunaan bangunan pada kawasan sekitar dan sebagai ruang transit.

○ Tempat berjualan pedagang kaki lima \& jasa entertainment

○ Sebagai paru-paru kota \& ruang evakuasi bencana

Dimensi Fungsional menelaah bagaimana ruang kota mampu mendukung dan memfasilitasi aktivitas. Dimensi fungsi terutama dikaitkan dengan kebutuhan manusia mulai dari yang paling dasar. Dimensi fungsi akhirnya juga berkaitan erat dengan dimensi sosial mengingat manusia adalah makhluk sosial yang tidak terlepas dari kehidupan kolektifnya. Faktor kenyamanan menjadi penting karena dapat memberi kenikmatan bagi para pengguna. Faktor kenyamanan dapat dilakukan dengan memberikan fasilitas tempat duduk yang tidak menghadap langsung pada matahari, tempat pemberhentian yang nyaman untuk menunggu bus dan juga dapat melakukan pelebaran trotoar sesuai kebutuhan sehingga kebutuhan ruang pedestrian terpenuhi.

\section{Dimensi Sosial}

Carr dalam Carmona, et al (2003) menyebutkan bahwa ada peran dari mengemukakan adanya peran dari aktivitas pasif maupun aktif pada penggunaan ruang publik. Pembentukan nilai pengalaman terbentuk dari terjadinya proses interaksi pasif dan aktif, hal menunjukkan bahwa pemanfaatan dari ruang publik terjadi oleh interaksi dengan proses yang berbeda. Interkasi sosial merupakan hasil dari suatu ruang dengan kondisi lingkungan nyaman sebagai wadah interaksi. Dari hanya aktivitas pasif seperti hanya duduk menikmati ruang disekitar saja dapat menjadi aktif saat muncul obrolan antar pengunjung ruang untuk saling berinteraksi

Mustika Kusumaning Wardhani I 11 Titik Nol Kilometer Kota Yogyakarta ... 
membahas suatu hal baik secara berdua maupun secara komunitas, hal ini menunjukkan bahwa interaksi sosial telah terjadi melalui aktivitas pasif-aktif.
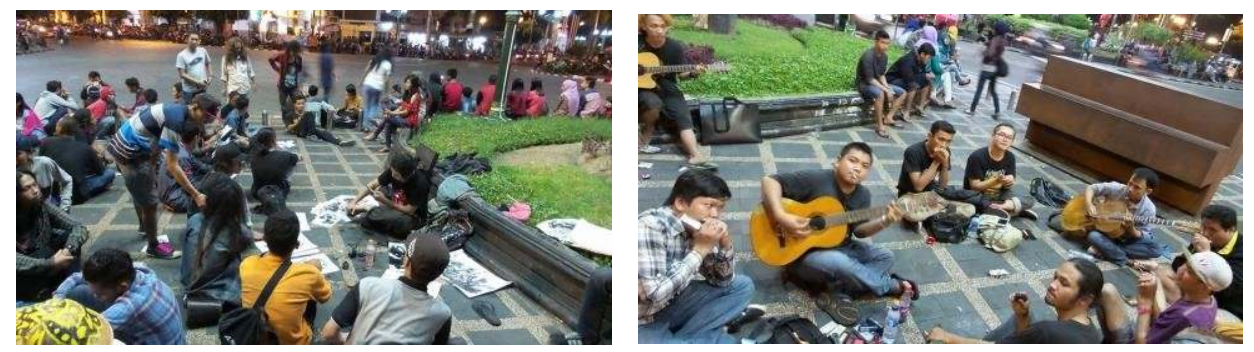

Gambar 7. Kegiatan sketsa bersama dan belajar bermain musik bersama sebagai respon komunitas pada penggunaan ruang terbuka publik

Sumber: Dokumentasi Pribadi, 2017

Munculnya aktivitas kreatif didalam ruang terbuka baik untuk komersial ataupun non komersial, memicu masyarakat untuk saling berinteraksi atau memberikan tanggapan pada kegiatan-kegiatan tersebut, hal ini juga berlaku pada peletakan suatu karya seni didalam ruang publik. Pada ruang publik ini dapat ditemui kegiatan sosial mulai dari jasa entertainment, tempat berkumpul komunitas, sketsa bangunan-bangunan kuno, tempat berjualan souvenir dan juga tempat transit.
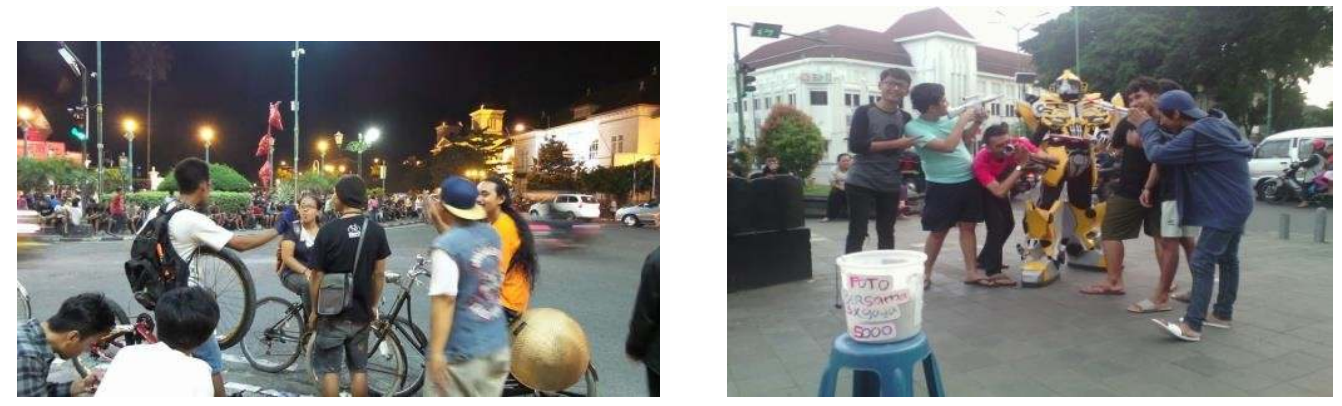

Gambar 8. Komunitas sepeda yang selalu melakukan kegiatan bersepeda bersama pada hari jumat dan jasa entertainment yang terdapat di kawasan titik nol Kilometer

Sumber: Dokumentasi Pribadi, 2017

\section{Dimensi Visual}

Keragaman visual menarik yang ditawarkan kawasan titik nol kilometer yang notabene adalah kawasan revitalisasi sangat berperan penting dalam menambah nilai pemandangan (vista). Bangunan Kantor Pos, Bank BNI dan Bank Indonesia meningkatkan 
daya tarik dan nilai estetika ketika pengguna sedang duduk dan berjalan disekitar kawasan titik nol kilometer.

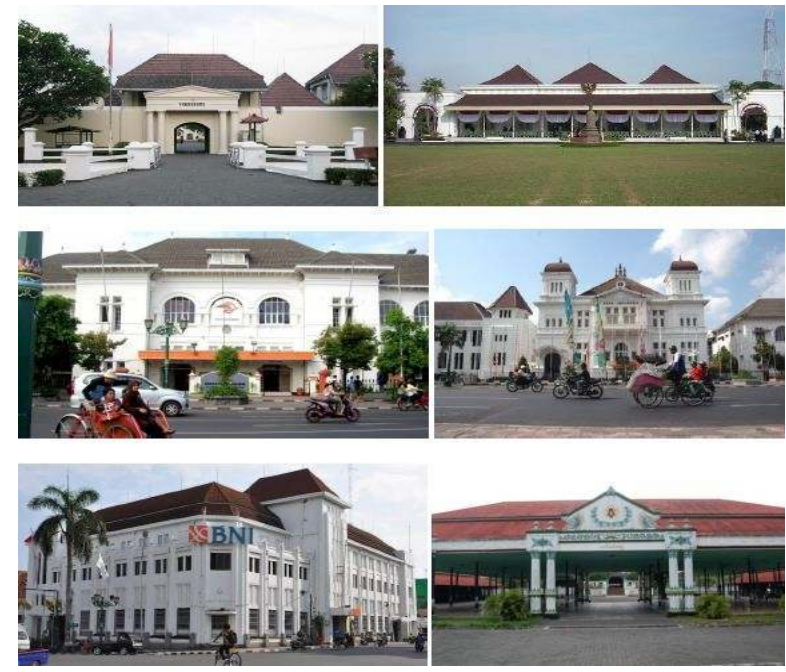

Gambar 9. Beberapa Landmark bangunan yang ditawarkan di sekitar kawasan titik nol kilometer Kota Yogyakarta Sumber: Dokumentasi Pribadi, 2017

Kesan terhadap suatu ruang akan berkaitan dengan seberapa serasinya kualitas visual kawasan yang ditunjukkan melalui unsur focal point-nya dan eksistensinya. Faktor pencapaian menuju titik nol kilometer sangat penting terutama bagi pejalan kaki dan orientasi para pengguna moda transportasi untuk mengenali tempat parkir saat akan menikmati ruang publik. Keberadaan ruang terbuka inilah yang berfungsi sebagai tempat transit para wisatawan yang berjalan cukup jauh dan secara visual, para pengamat dapat menikmati bangunan-bangunan bersejarah sehingga menambah daya tarik kawasan baik secara tangible dan intangible dengan pendekatan sense of place.

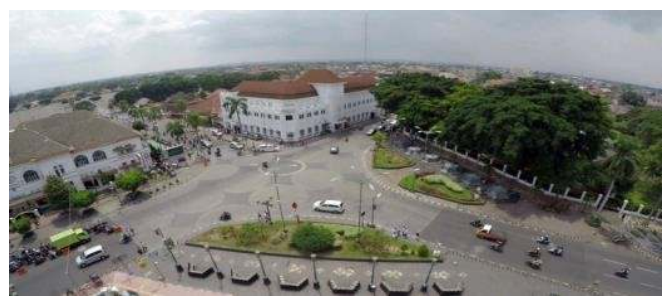

Gambar 10. Kawasan titik nol kilometer Kota Yogyakarta dilihat dari satelit pada sore hari yang memperlihatkan hierarki jalan yang cukup jelas

Sumber: Dokumentasi Pribadi, 2017 

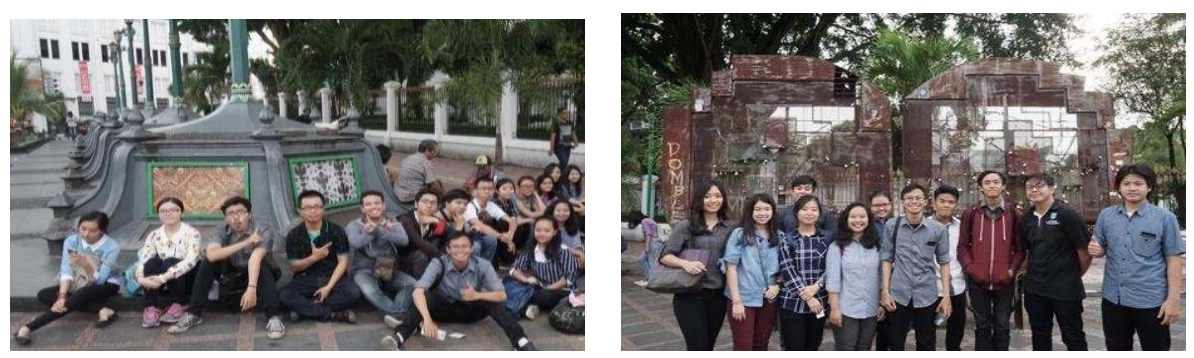

Gambar 11. Diorama mini sevagai sarana pengenalan batik dan tempat berfoto para pengunjung Sumber: Dokumentasi Pribadi, 2017

Sebagai tempat rekreasi untuk menghilangkan rasa jenuh, taman kota seharusnya dimanfaatkan sebaik mungkin. Fungsi taman kota berkaitan erat dengan fungsi kenyamanan untuk semua orang yang mengunjunginya (Nugroho, Hafidz Bjaktiyar Jati; Arsi, Ayuning Asri ; Akhiroh, 2017). Manajemen ruang publik kota merupakan pengamatan tentang bagaimana orang menggunakan semua bentuk ruang publik seperti jalan, taman, plasa, dan fasilitas transportasi umum (Shirvani. H, 1985). Pada ruang terbuka publik titik nol kilometer kota Yogyakarta jalan utamanya menghubungan kawasan Malioboro dengan kawasan Keraton dimana kedua kawasan tersebut adalah kawasan wisata bersejarah yang sangat berpengaruh terhadap sejarah per- kembangan Kota Yogyakarta yang juga dilalui oleh berbagai macam moda transportasi dan salah satu yang menjadi ciri khas Yogyakarta adalah keberadaan andong dan becak yang melintas.
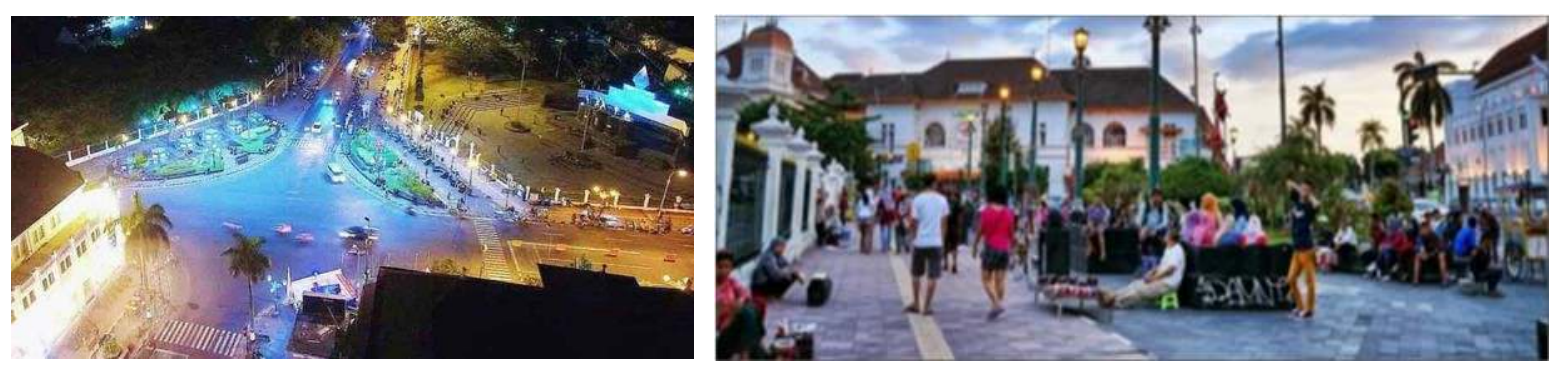

Gambar 12 Ruang terbuka publik kawasan titik nol dilihat dari satelit pada malam hari dan dilihat secara lansekap pada sore hari Sumber: www.google.com dan Dokumentasi Pribadi, 2017

Kebanyaan dari pengguna ruang publik adalah wisatawan mancanegara yang ingin menikmati keindahan kawasan Malioboro hingga Keraton. Secara temporal, intensitas penggunaan ruang terbuka publik titik nol kilometer akan lebih ramai digunakan oleh masyarakat dan wisatawan mulai sore hingga malam hari. 


\section{KESIMPULAN DAN SARAN}

\section{Kesimpulan}

Dari hasil yang analisis yang telah dilakukan, maka didapatkan hasil bahwa:

1) Kawasan titik nol kilometer merupakan ruang terbuka publik yang memuat berbagai macam kegiatan yang membentuk interaksi sosial penggunanya dari berbagai kalangan masyarakat.

2) Kawasan titik nol kilometer ditinjau dari dimensi fungsi, sosial, dan visual membentuk sense of place dengan karakter yang kuat, unik, dan khas.

3) Kawasan titik nol kilometer memiliki keseluruhan elemen pembentuk citra kota meliputi path, district, edges, nodes, and landmark

\section{Saran}

Dengan terpeliharanya ruang terbuka publik yang berfungsi mewadahi kegiatan interaksi sosial masyarakat pada satu kawasan maka akan memberikan ikatan berkesinambungan yang erat, antara masa lalu, masa kini dan masa datang. Hal tersebut dapat dilakukan dengan mempertahankan karakter visual yang ditawarkan, interaksi sosial antar masyarakat bersifat unity in diversity (no barrier), dan fungsi public space yang juga memperhatikan aksesbilitas pengguna (ramah difabel). Selain daripada hal tersebut, perlu diterapkannya manajemen ruang publik kota seperti perhatian terhadap perawatan dan keamanan, menciptakan pasar di pusat kota yang menarik dan berkualitas, dan senantiasa meningkatkan desain ruang-ruang publik guna menjamin integrasi fungsi ruang.

\section{DAFTAR PUSTAKA BUKU}

Adiprasetio, J., \& Jaya, S. (2017). Taman Alun-Alun: Produksi Ruang ( Sosial ) Dan Kepublikan. Common, 1(2), 118-129.

Ardani, Krisna Sandy; Rini, Hartati Sulistyo; Iswati, R. (2016). Pemanfaatan dan pemaknaan ruang publik bagi masyarakat di kawasan jalan pahlawan kota semarang, 5(1), 2-9.

Carmona, et al. (2003). Public places - Urban Spaces, The Dimension of Urban Design. Architectural press

Darmawan, Edy. (2009). Ruang Publik dalam Arsitektur Kota. Semarang: Badan Penerbit Universitas Diponegor 
Firdausi, Fairuuz Syafiqoh; Prsetyo, E. Y. (2017). Pendekatan Transprogramming untuk Mewujudkan Efisiensi Ruang berdasarkan Perubahan Aktivitas dan Waktu. Jurnal Sains Dan Seni POMITS, 6(2), 178-181.

Gani, R. (2017). Taman Kota Sebagai Modal Sosial Dan Interaksi Masyarakat Kota Bandung. Jurnal Signal Unswagati Cirebon, 5(1), 1-11.

Kostof, Spiro, and Richard Tobias. 1999. The City Shaped: Urban Patterns and Meanings through History. Boston: Little, Brown and Co

Lynch, Kevin. (1960). The Image of the City. Cambridge [Mass.]: Technology Press ;MIT Press ; Massachusetts Institute of Technology

Nugroho, Hafidz Bjaktiyar Jati; Arsi, Ayuning Asri; Akhiroh, N. S. (2017). Perilaku Sosial Remaja Dalam Memanfaatkan Ruang Publik Perkotaan (Studi Kasus Pemanfaatan Taman Kota Pleret Banjir Kanal Barat Semarang). Solidarity, 6(1), 1-13.

Prasetya, E., \& Hidayati, D. (2016). Analisis Tingkat Kenyamanan Ruang Terbuka Hijau (RTH)

Taman Kota Tengah, Taman Rekreasi Damai dan Taman Smart Nursery di Kota Gorontalo. In Seminar Nasional Lembaga Penelitian UNM (pp. 285-291).

Puspasari, R., Ernawati, J., \& Suryasari, N. (2015). Pola Aktivitas Pada Ruang Publik Taman Bungkul Surabaya. Jurnal Mahasiswa Jurusan Arsitektur, 4(2), 17-24.

Rahman, B. (2017). Peran Teknologi Game Berthema Simulasi Pembangunan Kota Terhadap Persepsi Pembentukan Penataan Pola Ruang Kota. dalam Seminar Nasional Smartcity (hal. 123-134), Semarang.

Setiawan, T. S. M. D. (2017). Persepsi Publik Pada Pengelolaan Taman Kota Di Kota Bandung Public Perception Of City Park Management In Bandung City. Jurnal Wacana Kinerja, 20(1), 1-18.

Trancik, Roger. (1986). Finding Lost Space: Theories of Urban Design. New York: J.Wiley www.google.com, diakses pada tanggal 10-5-2017

www.wikipedia.com, diakses pada tanggal 13-5-2017

Yunus, Hadi Sabari. ( 2000). Struktur Tata Ruang Kota. Yogyakarta: Pustaka Pelajar Zahnd, Markus. (1999). Perancangan Kota Secara Terpadu. Yogyakarta: Penerbit Kanisius 